\title{
Supply Chain Analysis Fresh Fruit Bunches Of Palm Oil
}

\author{
${ }^{1}$ Agribusiness Study Program, Graduate School Hasanuddin University, Makassar,90245, Indonesia \\ ${ }^{2}$ Agribusiness Study Program, Graduate School Hasanuddin University, Makassar,90245, Indonesia \\ ${ }^{3}$ Agribusiness Study Program, Graduate School Hasanuddin University, Makassar,90245, Indonesia \\ ${ }^{4}$ Agribusiness Study Program, Graduate School Hasanuddin University, Makassar,90245, Indonesia
}

${ }^{1}$ Anggi Aprilia Palupi $\quad{ }^{2}$ Ahmad Ramadhan Siregar ${ }^{3}$ Mahyuddin ${ }^{4}$ Sitti Nurani Sirajuddin

Correspondence Author: Anggi Aprilia Palupi, Agribusiness Study Program, Graduate School Hasanuddin University Makassar, 90245 HP:085216405010

E-mail: Anggiaprilia@pasca.unhas.ac.id

Received date: 23 February 2019, Accepted date: 22 May 2019, Online date: 30 May 2019

Copyright: (C) 2019 Anggi Aprilia Palupi et al., This is an open-access article distributed under the terms of the Creative Commons Attribution License, which permits unrestricted use, distribution, and reproduction in any medium, provided the original author and source are cre dited.

\begin{abstract}
This study aimed to analyze the supply chain process of fresh fruit bunches of palm oil. Based in Central Mamuju Regency, Province West Sulawesi. This research was conducted in February - April 2019 in the topoyo and budongbudong sub-districts. The data used in the study consisted of primary and secondary data. The population of this research is oil palm farmers in the topoyo and budong-budong sub-districts. The first sample determination of this analysis was done by purpossive sampling, there are $\mathbf{3 0}$ farmers who have farm land upstairs 5 years. And than, for some sample of institution that who still related with supply chain of fresh fruit bunches of palm oil. futhermore depended by snowball sampling methode, when the sample was found by respondence's information before, there were farmer's palm oil with following groove suply fresh fruit bunches start from farmer until palm oil factory. Research methods used include: 1) Identifying all members of the supply chain, and identifying relationships between members of the supply chain; 2) Analyzing supply chain configurations that include the management of three types of flows, namely the flow of products, money and information. The results of the study show that the flow of products, information and finance from the Supply chain of Fresh fruit bunches varies according to the choices of farmers in marketing their Fresh fruit bunches. Fresh fruit bunches products from partner farmers (supply chains 2 and 3 ) are generally of better quality compared to Fresh fruit bunches originating from collectors (supply chain 1) because they do not experience storage. In addition, partner farmers (supply chains 2 and 3 ) get convenience in terms of assistance from the company. Generally, Fresh fruit bunches Palm Oil Fruit prices from partner farmers (chains 2 and 3) are higher when compared to farmers (chain 1) who sell out Fresh Palm 0il Fruit to collectors. How to pay farmers who sell Fresh fruit bunches Palm Oil to collectors (chain 1) in cash, while how to pay partner farmers (chains 2 and 3 ) on credit.
\end{abstract}

Keywords Supplychain, fresh fruit bunches of palm oil

\section{INTRODUCTION}

Currently, Indonesia is the largest producer of crude palm oil (CPO) in the world. In 2016, the estimated plantation area was 13 million hectares [1]. This illustrates that the oil palm plantation sector is very increasing and very good to be developed and cultivated. However, despite many positive things, the selling price of oil palm fresh fruit bunches (FFB) has actually declined. This indicates that the supply chain and the policies of the CPO industry in Indonesia tend to be less prosperous for farmers. Therefore, the idea of appropriate technology is needed for the simplification of agricultural supply chains [2]. Oil palm is a double-edged sword. On the one hand, oil palm shows GDP growth and the national economy.

On the other hand, oil palm is a driver of the level of deforestation, forest fires, exploitation of natural resources and other environmental and social damage. Global efforts to develop oil palm sustainably and without conflict have been carried out to meet the needs of a transparent and traceable supply chain. If we can trace the palm oil supply chain, the main source of palm oil products can be tracked to ensure that production is obtained and produced legally in areas that are free of social and environmental conflicts. However, this supply chain is very complicated. To trace the supply chain, we must understand this complexity[3].

The framework of supply chain indicates behaviour and interaction of complex companies. Hence, the supply chain should be designed in a way that chain network characteristics and interactions are taken into account [4]. Supply chain is a chain or 
network of companies that work together to create and distribute products or services to end consumers. These circuits or networks range from raw material miners (upstream) to retailers/shops (downstream) [5]. Cluster supply chain is a collaborative network of organizations to maximize the value of the end products to customers, make quick decisions, decrease cycle time and increase flexibility in response to customer demand [6] SCM involves the integration of three key flows across the boundaries of the companies in a supply chain - product/materials, information, and finance/cash [7]. The logistics and supply chain management are no doubt one of the key success, should the country and its economy be competitive and survive [8]. the method of contract farming will give positive results if they are only a few players in the supply chain [9].

Furthermore, the supply chain of actors in the downstream supply chain gets more added value than the supply chain internal and upstream supply chain actors[10]. In some cases, the payment process for Fresh Fruit Bunches has several choices of marketing chain paths that farmers travel. There are some oil palm farmers who sell their Fresh fruit bunches Palm Oil Fruit to marketing institutions rather than selling their crops directly to the factory, this is done by farmers so that farmers receive money more quickly from their sales even though their crops are bought cheaply compared to directly selling the produce to the factory but have to wait one month to process the payment. In order to develop oil palm sustainably without conflict and its relation to farmers' welfare, complete information is needed on the supply chain of palm oil Fresh Fruit Bunches among oil palm plantation business actors, especially smallholder plantations in Central Mamuju Regency.

\section{RESEARCH METHODE}

This research was conducted in Central Mamuju, West Sulawesi Province as the largest oil palm production in the eastern Indonesia region with the boundaries of the Budong-Budong District and Topoyo District because the two locations were the nearest locations to the three palm oil processing companies. This type of research is a qualitative descriptive study. The data used in this study consisted of primary data and secondary data. Primary data is data obtained through direct observation and in-depth interviews with respondents using a questionnaire. Secondary data is obtained from related institutions. The study population was oil palm farmers in Budong-Budong and Topoyo Districts. The first sample determination in supply chain analysis of Palm Oil Fresh Fruit Bunches was carried out by purposive sampling method, namely for oil palm farmers who have over 5 years of oil palm plantations of 30 people. Then, for a sample of several institutions that are still related to the supply chain of oil palm FFB, it is then determined by snowball sampling method where samples are obtained based on information from previous respondents, namely oil palm farmers by following the oil palm FFB supply path from farmers to oil palm companies. Research methods used include: 1) Identifying all members of the supply chain, and identifying relationships between members of the supply chain; 2) Analyzing supply chain configurations that include the management of three types of flows, namely the flow of goods, money and information.

\section{RESULT AND DISCUSSION}

Parties in the FFB supply chain in Mamuju Tengah District include: farmers and collectors as marketing institutions. Harvesting of FFB is carried out by oil palm farmers, twice in 1 month. The results of the oil palm farmer transportation are then collected at TPH (Harvesting Place), then after being collected it will be transported by dump truck or pickup to the collector or directly to the company. The results showed that the FFB supply chain in Central Mamuju District had 3 patterns of FFB supply chain flow in the company, there are :

The district had 3 patterns of FFB supply chain flow in the company, there are :

$\begin{aligned} \text { farmer } 1 & \longrightarrow \text { collector } \longrightarrow \text { PT Primanusa Global Lestari } \\ \text { farmer } 2 & \longrightarrow \text { PT Surya Raya Lestari II } \\ \text { farmer } 3 & \longrightarrow \text { PT Wahana Karya Sejahtera Mandiri }\end{aligned}$

\section{Flow Supply chain 1}

The pattern of supply chain 1 flow is the flow of FFB originating from farmers which are then channelled to the collector before the party PT Primanusa Global Lestari. there are three main actors in the FFB supply chain in the study area consisting of oil palm farmers, collectors, and palm oil mills. Whereas supporting actors in the oil palm FFB supply chain consist of harvest workers, transport leasing institutions, plantation offices, financial institutions. The pattern of supply chain 1 has product activity, namely FFB. The flow of FFB in this pattern must pass through one marketing agency in selling FFB to PT. Primanusa Global Lestari. The marketing agency is a collector. Farmers as the main actors in producing FFB. The harvested FFB will be directly sold to the collector and then the collector will sell directly to PT. Global. Collectors act as SPK holders (Contract holders) or Delivery Orders (DO). FFB sold to marketing institutions, collectors sometimes experience storage no later than 2 days before FFB is sold to PT. globally. The storage was carried out because the amount of FFB obtained did not meet the capacity of the truck or when it coincided with the company's factory holiday. Storage of FFB carried out by collectors will have a negative impact on the quality of FFB itself. This means that the longer the FFB supply chain, the quality of FFB will decline due to the treatment of marketing institutions.

The company always provides information on price changes to the collector, then the collector continues the price change to the farmer. The information is then disseminated to oil palm farmers when they sell FFB. From the results of the study, there were 
farmers who did not know about the price of FFB that occurred at PT. Global, so farmers do not feel they get a low price from the collector. But there are also farmers who feel that the standard price of the Provincial Plantation Service is not much different from the price set by the collector, so the farmer sells to collectors whose prices do not deviate far enough from the standard price set by the government. The company itself provides price subsidies from the prices set by the local plantation service. At present the average price of suppliers to farmers in February was Rp. 972 / kg and the price of the company to collectors was Rp. 1200 / $\mathrm{kg}$. In terms of technical assistance, collectors and farmers say that they use their own funds or from their own side. PT Global does not know for sure the farmers who supply their FFB to collectors. Because the company only partnered with collectors with provisions to supply 30 tons of FFB per week. Likewise with collectors, because they do not have a contract with the farmers who supply FFB, the collectors do not know for sure the farmers. The method of payment made by collectors with farmers is cash or cash. The collector directly pays for the FFB he has bought. Payments made by collectors to farmers are in cash during the process of buying and selling FFB. The purchase price of FFB determined by collectors has been estimated based on how much marketing costs they bear. While the method of payment made by companies with collectors is on credit. At PT Global it is done once a week. Payments are made collectively through financial institutions sent directly to collectors.

\section{$\checkmark \quad$ Flow supply chain 2}

The pattern of supply chain 2 flow is the flow of FFB originating from farmers and then channelled to the PT Surya Raya Lestari 2. there are three main actors in the FFB supply chain in the study area consisting of oil palm farmers, farmer groups and palm oil mills. Whereas supporting actors in the oil palm FFB supply chain consist of harvest workers, transport leasing institutions, plantation offices, financial institutions. In the pattern of supply chain flow 2 farmers directly send FFB obtained through farmer groups to PT Surya Raya Lestari 2. On FFB 2 flow has a good in the quality of FFB, because FFB obtained from farmers is sent directly to the company. PT. Surya Raya Lestari 2 always provides information via Whatsapp messages or phone calls to the chairman of the farmer group if they experience price changes. In addition, farmers also know the prices of the provincial plantation service. The company provides price subsidies from the prices set by the local plantation service. Changed prices are then applied to the purchase of FFB to farmers. Currently, in February, the price set by the company to farmers is Rp $1013.11 / \mathrm{kg}$. If the farmers experience problems in channelling FFB because of constraints to road damage. The farmer will report to the head of each farmer group, then the head of the farmer group will forward the report to the company for assistance. The flow of mo ney that occurs in farmer groups and farmer members comes from companies. FFB that has been distributed to the factory will be paid by the company through the farmer group account within 1 month after the FFB is transported to the company. After that, the farmer group will share the proceeds from the sale of FFB to each farmer.

\section{$\checkmark \quad$ Flow supply chain 3}

The pattern of supply chain 3 flow is the flow of FFB originating from farmers and then distributed to PT Wahana Karya Sejahtera Mandiri. There are three main actors in the FFB supply chain in the study area consisting of oil palm farmers, farmer groups and palm oil mills. Whereas supporting actors in the oil palm FFB supply chain include of harvest workers, transport leasing institutions, plantation offices, financial institutions. In the supply chain pattern, 3 farmers directly send FFB obtained through farmer groups to PT Wahana Karya Sejahtera Mandiri. PT Wahana Karya Sejahtera Mandiri always provides information via Whatsapp messages or phone calls to the head of the farmer group if they experience price changes. Besides, farmers also know the prices set by the provincial plantation service. Companies generally provide subsidies from prices set by the local plantation service. Currently, in February, the price set by the company to farmers is Rp $1060.11 / \mathrm{kg}$. If the farmers experience problems in channelling FFB because of constraints to road damage. The farmer will report to the head of each farmer group, then the head of the farmer group will forward the report to the company for assistance. FFB that has been distributed to the factory will be paid by the company through the farmer group account within 1 week after the FFB is transported to the company. After that, the farmer group will share the proceeds from the sale of FFB to each farmer.

\section{CONCLUSION}

The product, information and financial flows from the FFB supply chain vary according to the choice of farmers in marketing their FFB. FFB products from partner farmers (supply chains 2 and 3) are generally of better quality compared to FFB originat ing from collectors (supply chain 1) because they do not experience storage. In addition, partner farmers (supply chains 2 and 3 ) get convenience in terms of assistance from the company. Generally, FFB prices from partner farmers (chains 2 and 3) are higher when compared to farmers (chain 1) who sell out FFB to collectors. How to pay farmers who sell FFB to collectors (chain 1) in cash, while how to pay partner farmers (chains 2 and 3) on credit.

\section{REFERENCES}

[1] Kontan News,2018. Kemtan: Luas lahan perkebunan sawit saat ini capai 13 juta ha. Downloaded . february 2019 Available from :URL:HYPERLYNK https://industri.kontan.co.id/news/kemtan-luas-lahan-perkebunan-sawit-saat-ini-capai-13-juta-ha

[2] Mega L P .2015. Simplifikasi Rantai Pasok Pertanian, Mahasiswa ITB Juarai PIMPI 2015. Downloaded . february 2019 Available from :URL:HYPERLYNK https://www.itb.ac.id/news/read/4915/home/simplifikasi-rantai-pasok-pertanianmahasiswa-itb-juarai-pimpi-2015 
[3] Widyapratami Hermawati 2018. Membangun Kemampuan Penelusuran Kelapa Sawit dalam Rantai Pasokan Indonesia yang Kompleks. Dowloaded may,2019. Available from : URL :HYPERLYNK https://wri-indonesia.org/id/blog/membangunkemampuan-penelusuran-kelapa-sawit-dalam-rantai-pasokan-indonesia-yang-kompleks

[4] Rashidi SF, Barati Ramin.2014. On the Comparison of Supply Chain with Sub-Dmus in Dea. Advances in Environmental Biologi. 8(7) 2387-2390

[5] Kartika N R.2015. Supply chain Management. Jakarta : Gunadarma University

[6] Purnomo, A. (2014). Cluster analysis of supply chain performance small industrial shoe Cibaduyut, Indonesia. Australian Journal of Basic and Applied Sciences, 8(2), 106-114.

[7] Nasrun Mohd, Nawi Mohd .2014. A Review of Supply Chain Management Issues in Malaysian Industrialised Building System (IBS) Construction Industry. Australian Journal of Basic and Applied Sciences. 8(5) 533-538

[8] Ramingwong Sakgasem, Sapodang Apichat.2015. Simulating Benefits over Supply Chain Redesign Strategies. Journal Of Applied Sciences Research. 11(20) 7-10

[9] Widyadana, G. A., Octavia, T., Palit, H. C., \& Gunawan, G. A. (2014). The Impact of Contract Farming on Banana Supply Chain Performance in East Java, Indonesia. Australian Journal of Basic and Applied Sciences, 8(14 Special), 90-95.

[10] Sirajuddin, S. N., Mappangaja, A. R., Darma, R., \& Sudirman, I. (2015). Value added analysis of beef cattle supply chain actors micro-scale community farm based. American-Eurasian Journal of Sustainable Agriculture, 9(7), 7-12. 